\title{
'From rhetoric to practice: a critique of immigration policy in Germany through the lens of Turkish-Muslim women's experiences of migration'
}

\author{
Sherran Clarence
}

\begin{abstract}
The largest group of migrants in Germany is the Turkish people, many of whom have low skills levels, are Muslim, and are slow to integrate themselves into their host communities. German immigration policy has been significantly revised since the early 1990s, and a new Immigration Act came into force in 2005, containing more inclusive stances on citizenship and integration of migrants. There is a strong rhetoric of acceptance and open doors, within certain parameters, but the gap between the rhetoric and practice is still wide enough to allow many migrants, particularly women, to fall through it. Turkish-Muslim women bear the brunt of the difficulties faced once they have arrived in Germany, and many of them are subject to domestic abuse, joblessness and poverty because of their invisibility to the German state, which is the case largely because German immigration policy does not fully realise a role and place for women migrants. The policy also does not sufficiently account for ethnic and cultural identification, or limitations faced by migrants in that while it speaks to integration, it does not fully enable this process to take place effectively. Even though it has made many advances in recent years towards a more open and inclusive immigration policy, Germany is still a 'reluctant' country of immigration, and this reluctance stops it from making any real strides towards integrating migrants fully into German society at large. The German government needs to take a much firmer stance on the roles of migrant women in its society, and the nature of the ethnic and religious identities of Muslim immigrants, in order to both create and implement immigration policy that truly allows immigrants to become full and contributing members to German social and economic life, and to bring it in line with the European Union's common directives on immigration.
\end{abstract}

Keywords: ethnicity; European Union; exclusion; Germany; guest workers; immigration; immigration policy; Turkish-Muslim women.

\section{Introduction}

Germany has recently implemented a new Immigration Act (2005) after a lengthy process of negotiation and debate, and has been struggling with issues of self-definition related to whether or not it is indeed a 'country of immigration'. 
Germany has a long history of xenophobia and violence towards perceived outsiders, and has never really regarded itself as a country of immigration. This stance has been reformulated in recent years, and the federal government in 2004, under the leadership of Gerhard Schroëder, declared Germany a country of immigration. German immigration and integration policy is now being reconsidered under the leadership of Chancellor Angela Merkel and the Christian Democratic Union, but no significant changes have been made to the 2005 Act as yet. Germany is thus an interesting case study in terms of the shifts that have occurred and are still occurring in thinking and policy formulation around the issue of immigration. It has been suggested that, as one of the biggest countries in the EU, Germany has a considerable amount of influence over policy-making at the supranational level, and that whatever it decides to do with its immigration policy will have an impact on the shape of European policy (Martin, 2001). Certainly this was borne out in 2003 when Germany foiled the EU's plans to create a common immigration policy (Schlagheck, 2003). Germany provides us with an opportunity to examine some of the key challenges related to recruiting and integrating migrant communities with very different cultural and religious beliefs and practices to those of the receiving country, and also some of the key trends with regards to immigrant women and their particular problems and difficulties.

The new German Immigration Law is designed to address demographic issues that are causing a decline in the number of working-age Germans entering the labour market, and a steady increase in the number of people leaving the labour market. Germany registered the lowest fertility rate in the EU in 1999, with an average of 1.3 children per woman, well below the 2.1 needed to maintain the size of the country's population (Green, 2004). The EU's collective population is expected to fall to below its current numbers by 2050, and similarly in Germany, as a result of current fertility rates, the German population is predicted to shrink from 80 million to between 60 and 70 million by 2050 (Green, 2004). To compound this, the combination of pensioners living even longer due in great part to advances in medical science and care, and fewer people working to pay the taxes necessary to maintain pension and health care systems will culminate in a social security and pension systems crisis at some stage during the first half of the $21^{\text {st }}$ century (Green, 2004). These factors combine to create a situation in which immigrants, preferably skilled, are needed to fill gaps in the workplace, and are desired to settle in Germany and have families that will continue to contribute to Germany's social and economic future.

However, in spite of the strong realisation on the federal governments' part of the necessity of immigration, and a declaration of Germany as a country of 
immigration, there is still a strong sense that Germany is reluctant to fully embrace its new political, economic and socio-cultural reality. There are still significant gaps between the rhetoric of immigration and the actual implementation, and again between the implementation and its recognition of the realities of Muslim immigrants' lives. Germany has been recently criticised by the Organisation for Economic Cooperation and Development (OECD) for admitting lower numbers of permanent immigrants than other Western European countries, thus neglecting the needs of the work-force, and for lagging behind other EU member states in admitting low-skilled migrants and recognising foreign qualifications (DW-World, 2008). It is also worth noting that the word 'reluctant' appears in quite a number of articles discussing German migration policy. This seems to relate, in the focus of this paper, to the integration of migrants into German society, and the recognition of migrants as part of the German citizenry and broader social and cultural context. This reluctance is particularly noticeable when one considers Turkish-Muslim women migrants and the ways in which they negotiate the policy and practice of immigration and then integration into their host communities. It is also related quite closely to the lack of obvious consideration in policy formulation and implementation of the specific, and firmly held, cultural and religious beliefs and practices of Turkish immigrant groups.

This paper will argue, through a keen focus on the more significant problems and issues that Turkish-Muslim immigrant women confront during and after the process of immigration, that Germany cannot afford to continue its pursuit of limited and reluctant immigration and integration policies. This paper will look at the ways in which limited thinking on the part of German policy-makers about the kinds and nature of Muslim immigrants' settlement patterns and religious and cultural affiliations, as well as the new requirements for gaining citizenship, constrains the practice of integration, to the extent that integration is happening at only a superficial level and fails to address the lived realities of TurkishMuslim immigrants in general and women in particular. This paper will consider various aspects of immigration policy that either exacerbate or attempt to solve problems related to immigration and integration, and will suggest possible solutions and policy adjustments that could be made to facilitate a less disruptive and discriminatory immigration process for these women and their families. For example, the issue of guaranteed rights and secure legal status is of particular importance to immigrant women. Many women enter the Union through the mechanism of family reunification and are thus dependent on their spouses for their livelihood. This dependent legal status is at the centre of the debate on immigrant women's rights in the EU, and many of the other difficulties that these women face can be connected to this. It is also important to consider immigrant 
women's lives on various levels, and to view them not only as dependent wives, mothers and daughters, but also as independent workers and people in their own right. A great deal of the existing literature deals with immigrant women narrowly, and considers them only as dependents, and as secondary to men in the process of immigration. The paper will also briefly consider some of the possible implications of xenophobic and racist violence for immigrants' integration and settlement patterns, and how the German government's reluctance to actively prosecute offenders adds to the withdrawal of Muslim immigrants into their own narrow ethnic and religious spaces, preventing meaningful and long-term integration and immersion.

\section{A reluctant country of immigration - the evolution of immigration policy}

To better understand the construction of Germany's immigration policy, and German attitudes towards immigration and immigrants, it will be useful to explore, briefly, the evolution of policy towards foreigners, known as Ausländerpolitik. 4 Germany was one of the European countries that participated in the guest worker recruitment schemes of the 1960s and early 1970s. Known in Germany as Gastarbeider ${ }^{1}$, these workers came into the country from both inside and outside of the European Community, mostly from the Mediterranean region. One of the largest groups of guest workers, now one of the largest ethnic groups in Germany, was the Turks (Hillmann, 1999: 270). After the oil shock in $1973{ }^{2}$ and the subsequent recession, Germany closed its borders firmly to labour migrants, and the Turkish immigrant population has grown since then as a result of natural growth and family reunification (Hillmann 1999: 270). Prior to the 1973 ban, 'four-fifths of all Turkish migrants to the Federal Republic of Germany3 were men, usually without their families (Davis and Heyl 1986: 182). In addition to male workers, the Federal Republic before the ban 'overwhelmingly' recruited Turkish women, and these women responded in 'considerable' numbers, often migrating on their own (Rist 1978, quoted in Davis and Heyl, 1986: 183). Since 1973, though, family reunification has been one of the only legal ways to gain entry into Germany, and most of the Turks migrating to join legally resident family members have been women and children (Davis and Heyl, 1986: 184).

Germany began recruiting workers from both inside and outside of the European Community in 1955.5 The basic principle of labour recruitment was the employment of preferably young, single men who would fill gaps in the less skilled sectors of industry and agriculture. These young men would ideally be given short-term work and residence permits, and once the labour contract expired they would return to their countries of origin (Green, 2004: 33). It is estimated that a total of 14 million guest workers entered Germany between 1955 
and 1973, of which about 11 million returned to their home countries. However, it became increasingly apparent that this was not a satisfactory system for both employers and unions, who wanted to avoid the costs of training new workers every few years, and the risk of foreign labour 'undercutting' the German workforce through cheaper contracts respectively (Green, 2004: 33). Guest workers began to receive permanent contracts, and there was increasing regularisation and settlement of foreign workers, but, remarkably, there was no formal legal framework for foreigner's residence in place until 1965.

The 1965 Ausländergesetz ${ }^{6}$ replaced the 1938 Nazi-enacted Ausländerpolizeiverordnung, but did little to improve foreigner's rights to residence. It placed the power firmly in the hands of the German state, giving it the power to decide whether or not a foreigner's presence in the country was in the 'Federal Republic's interests', and thus effectively made it easier for the state to both deny and revoke residence permits (Green, 2004: 35). This interpretation of the power relationship between the state and non-national residents, with the state firmly in control, came to be central to policy debates in subsequent decades. This version of the Ausländergesetz remained in force until 1990, although some revisions and alternate policy directions were considered during the early 1980 s. Underlying these revisions was the position that Germany was 'not a country of immigration' and was not seeking to 'increase the number of its citizens through naturalisation' (Green, 2004: 40). This reluctance to admit foreigners to German citizenship and to define itself as a country of immigration has been a feature of Ausländerpolitik even in the most recent round of policy debate and restructuring. The key feature of the 1980s Ausländergesetz review process was the restriction of migration for the purposes of family reunification.

During 1981, the government began to search for ways to restrict the migration of dependants of the largely male guest worker population. This type of migration was not covered in the 1965 Ausländergesetz and since 1973 it had become a significant source of immigration. The government decided to act to limit the conditions under which spouses could immigrate, and specifically aimed to lower from eighteen the age up to which children of foreigners could migrate to Germany (Green, 2004: 44). The restrictions applied then to family reunification then still largely apply today, and involve issues like housing, income and employment. To explain briefly, the settled (male) spouse must have housing of a certain size and legal employment that brings in a certain income before the German government will consider an application for family reunification. As in many European countries, finding adequate and affordable housing, especially in the larger cities where wages for immigrants are higher than in the less urban areas, but still lower than those of the non-immigrant population, is difficult. 
Thus, even though family reunification is a legal method for immigrating to Germany, it is not an easy method, and the Ausländergesetz in many ways ensures this. The policy was only reviewed again in 1990, when, under the leadership of Helmut Kohl, it was revised.

The key driver behind the 1990 revision was the integration of permanently settled foreigners, whose poor legal situation increasingly began to occupy the German political agenda. While the German government recognised the need to integrate existing immigrants and improve their legal and social standing through awarding permanent work and residence permits and increasing the range of socio-economic rights available to them, they were also reluctant to allow any further immigration to West Germany, and attempted to work restrictions on new immigration into the policy, a move that was widely rejected and that delayed further policy reform substantially (Green, 2004: 60-62). The final draft of the Ausländergesetz made only a few meaningful changes. For instance, the prerequisite of adequate living space for family reunification was relaxed slightly, and it made naturalisation a simpler and cheaper process 7 , allowing first-generation immigrants with over fifteen years' residence access to this simplified process for the first time (Green, 2004: 71). Most of the gains made for immigrants were incremental, and not really enough to ensure a more secure legal status.

The 1990s did not really see greater integration of the existing immigrant population and instead bore witness to a rise in xenophobic tendencies towards immigrant groups, and a resultant increase especially in larger cities like Berlin in the number of 'ethnic enclaves' 8 where immigrants could retreat into the safety of their own ethnic groups. The growth of the non-national population throughout the $1990 \mathrm{~s}$ and into the $21^{\text {st }}$ century, characterised by relatively low levels of naturalisation and higher levels of natural growth and family reunification, largely the means by which immigrant women enter Germany, has continued to make integration a pressing political issue. The formation of the EU in 1992, and subsequent EU-level directives on immigration and integration culminating in the Communication on community policy, as well as Green Papers on economic migration and demographic change coupled with the formation of the Women's Committees in the European Parliament and the European Women's Lobby among others, have made integration of immigrants a supra-national as well as national political issue. The need to re-open European borders to controlled labour migration made the need for another reformulation of Ausländerpolitik and the Ausländergesetz even more important for the German government in the early 2000s, when this process began, and is still vital today, as we begin to examine the implementation successes and failures of the 2005 Immigration Act. 


\section{The New German Immigration Policy and its relevance for Turkish- Muslim immigrants}

The current German federal government is led by the coalition of the SocialDemocratic Party of Germany (SPD) and the Christian democrats - the Christian Democratic Union (CDU) and its Bavarian sister party the Christian Social Union (CSU) (hereafter CDU/CSU/SPD) - which is broadly pro-cultural homogeneity and therefore uncomfortable with rights-based immigration and integration discourse. The previous German federal government until 2005, the government that succeeded in passing the new Immigration Act of 2005, was led by a broadlyspeaking Leftist in political orientation, pro-immigration and integration coalition between the SPD and the Green Party (the SPD/Greens). During their first period in office (1998-2002) under Chancellor Gerhard Schröder, the SPD/Greens introduced two crucial legislative initiatives in both citizenship and immigration policy which promised to completely redefine the structures, aims and methods of this policy area (Green, 2004: 9). This was welcome news for non-nationals, many of whom had been living in Germany for over twenty years in $1998^{9}$ yet still did not have access to rights and benefits comparable to those enjoyed by German citizens, and many of whom have to confront racial and xenophobic prejudice and violence in their daily lives. Certainly the SPD/Greens' intention was to overhaul immigration and citizenship policy, and immigration policy has thus been renamed and revised since 1998.

Now known as Zuwanderungsgesetz, ${ }^{10}$ re-characterising non-nationals as immigrants rather than as foreigners, the policy has made some major improvements on the old Ausländergesetz. However, critics of the policy argue that because of the way power is divided in Germany between the federal government and the Länder or states, giving the leaders of the latter enough power to redirect and change proposed legislation, and because of the sway the $\mathrm{CDU} / \mathrm{CSU}$ coalition held, and still holds, over public opinion where immigration is concerned, the new Zuwanderungsgesetz is less wide-ranging and progressive than the SPD/Greens wanted it to be. In its initial form, the bill 'was to regulate new, high-skilled labour migration, introduce new formal courses for nonnationals, improve the situation for refugees and provide a simplification of Germany's complex residence policy (Green, 2004: 111). After being negotiated in the Bundesrat ${ }^{11}$ for a significant period of time after its introduction in 2002, the Immigration Act was finally passed in June 2004, and the new Zuwanderungsgesetz came into effect in January 2005. The SPD/Greens had to make several compromises in order to push the final bill through both the upper and lower chambers of parliament, and thus the final product does not provide as much for non-nationals as it perhaps could have. It also leaves immigrant women 
in a precarious position in some cases, although in a few instances it assists them more than the proposed EU policy does.

There are three key areas that need to be examined and interrogated further: the first is that, while measures have been taken to ensure more focused and widespread integration of immigrants through language and civic education classes that the federal government pays for, the policy does not seem to have a major impact on the integration of Turkish-Muslim immigrants in their lived reality. The second is that, while the new policy does mention women, it leaves many gaps through which these migrant women can fall, at great costs to themselves and also to the German state - women are not focused on clearly or specifically enough in the policy. The final critique of the policy focuses on its unwillingness or inability to focus clearly and meaningfully on the social environment into which immigrants are asked to integrate themselves. Xenophobia and racist violence, based as it is on fear or aversion to a perceived 'other' is a serious obstacle to the full integration of immigrants, and ensuring their full immersion in German social, economic and political life. Linked to this problem is the issue of citizenship, which is still a contentious issue in Germany.

\section{Integration and immersion of immigrants}

Integration of immigrants into German cultural, social and political, as well as economic, life is a big focus of the 2005 Act, and presents a substantial challenge to the federal and state governments. Recent polls in Germany show that only one-third of Muslim immigrants actually want to integrate (Poggioli, 2008) and experts argue that Muslims 'integrate less and more slowly than non-Muslims' (Bisin et al., 2007: 1). Muslims have a stronger documented intensity of religious identity than non-Muslims. Their education levels do not seem to affect their identities - achieving higher levels of education does not seem to make them less attached to their particular religious and cultural beliefs and the identities thus derived - and 'job qualification as well as living in neighbourhoods with low unemployment rate seem to accentuate rather than moderate the identity formation of Muslims' (Bisin et al., 2007: 3). Further to this, discrimination, and xenophobic attitudes directed against them, consistently generates intense identity for Muslims (Bisin et al., 2007). This desire on the part of Muslims to move to Germany but remain within their narrow ethnic enclaves, which are formed through a high degree of internal solidarity and mutual assistance, as well as resistance to out-marriage, residential self-segregation, and cultural segregation from the host community (Hillmann, 1999: 268), presents an enormous and complex challenge for the German state, and for German society. They cannot force immigrants, Muslims in particular, to integrate and immerse themselves in German life, but without significant and meaningful integration, 
the kinds of abuse suffered by Muslim women, and the kinds of xenophobic violence directed at immigrants groups and their defenders (think of the recent murder of Theo van Gogh and the attacks on Indian immigrants in Germany in 2007) will continue and even intensify. The 2005 Act does take this to heart, and has made some positive steps towards moving from rhetoric to practice.

One positive thing the Zuwanderungsgesetz ensures is more visible efforts to integrate incoming immigrants through language and civic education classes. From now on, 'all newly arriving immigrants are entitled to attend language and integration classes' which have previously only been available to Aussiedler ${ }^{13}$ (Munz, 2004). These language classes are a very important focus of the policy documents on integration because "[l]anguage is the key to integration. Language skills alleviate the access to and the participation in societal areas; they are fundamental for successful education and increase the chances for the integration to the labour market' (quoted in Heinrich, 2007: 13). There is also provision for special integration classes for women - since 2007 the German government has become far more proactive and interested in concentrating on the successful integration of immigrant women, as officials believe their empowerment can facilitate the integration of their communities - and husbands and children into the mainstream (Heinrich, 2007; Poggioli, 2008). The cost of these classes was originally going to be partially carried by the immigrants themselves, but in the final version of the bill it is stated that the federal government will carry all of the costs. The language used is slightly ambiguous; it is stated that immigrants are 'entitled' to attend these classes, which will teach them the German language as well as aspects of German political and cultural life, yet it is more accurate to state that they are 'obligated' to take the classes. New and long-term immigrants who fail to complete these courses may find some of their social benefits being withheld, or may even have residence permit renewals denied (Munz, 2004; Heinrich, 2007). Thus, while the federal government is certainly shouldering far more of the responsibility for integrating immigrants, especially women, into German social and cultural life than it did prior to this, it still places a great deal of the onus for integrating on the shoulders of immigrants, some of whom may not be able to take advantage of these courses without adequate support from the government, and some of whom may choose not to do so.

A rational examination of the requirements of immigrants to attend integration and language classes, particularly in the case of women, may reveal some challenges that could impede immigrant women's participation. It would be particularly difficult, for example, for women immigrants to take language and civic education courses if they have children at home that need care, and if they have husbands or fathers that are reluctant to allow them to have extended 
contact with other immigrants or German nationals. Day care costs in Germany are high, and there are long waiting lists for places in many day care centres. Newly arriving immigrant women thus need support from the government in providing them with reliable childcare arrangements while they take these courses. Women (and men) who move immediately into jobs upon arrival need compensation for any time taken off from work to attend courses, and the childcare needs apply if courses are held in the evenings. The German government also needs to find ways to impress upon their husbands and fathers the importance of allowing women and girls to take these courses. The reporting of attendance and the implications of non-attendance on residence extension and naturalisation processes could go some way towards ensuring their compliance with the laws (Heinrich, 2007).

The availability of these courses to immigrants is an important step in the direction of successfully integrating immigrants into German society, but it needs to be implemented in such a way as to provide immigrants with the viable opportunities to take advantage of them. This part of the new law provides integration courses for newly arriving immigrants, but what about immigrants who have already been resident in Germany for some years and are unable to properly integrate because these opportunities have never been open to them? There is no apparent mention of free integration classes for already-resident immigrants, and no mention of withdrawing any of their social benefits if they do not choose to attend. Further, these courses are only offered in areas where there are large groups of immigrants, usually large cities and towns, and they are only available to legal immigrants - thus asylum seekers, refugees and undocumented women are excluded from these provisions (Heinrich, 2007). Certainly now that classes are open to all immigrants settled non-nationals should be encouraged to take advantage of these classes as part of a wider integration strategy, as it is apparent from some of the literature that even immigrants who have lived in Germany for as many as thirty years do not speak enough German to truly integrate into social and cultural life, mostly because they tend to live in ethnic enclaves and speak their native languages among their kinspeople. ${ }^{14}$

This new, more open position on integration reveals that the federal government is aware of the fact that immigrants struggle to integrate themselves into German cultural and social life, especially if they are unable to speak German. Women, in particular, suffer from isolation, especially those from more conservative cultural and religious backgrounds, like Muslims. While it is extremely difficult for the federal government to legislate for the private sphere, as is the case with the common EU framework, it has become apparent that many young Muslim women immigrating to Germany as wives and daughters are vulnerable to 
isolation and abuse that is invisible to the wider ethnic and German community. The government has attempted to take a stand on these issues, for example, denying both teachers and other public officials the right to wear headscarves at work in an attempt to enforce secularism (Spiegel Online, 2005). Many young Muslim women are prevented by their families from finding work or learning the German language, measures that would assist them in making friends and 'staking a claim' in their new home country - particularly in the case of long-term immigrants. Spiegel Online, a popular German political periodical, reported in November 2004 that 'social workers estimate that thousands - perhaps tens of thousands - of Muslim women live as invisibles in Germany, their lives physically defined by the walls of their home and ordered by four staples: the Quran, male superiority, the importance of family, violence and honor' (Spiegel Online, 2004). It is not clear how mandatory integration and language classes will help these immigrant women to escape from domestic violence, abuse and isolation. While equipping young women with the skills necessary to better negotiate life in Germany is arguably an essential part of an immigration policy, it is not enough to prevent the human rights abuses and exclusions that many of these young women endure.

Having considered the steps taken in the immigration policy to integrate immigrants, particularly women, into German society through language and civic education classes, I will not examine the particular challenges facing TurkishMuslim women in Germany, and begin to show up some of the shortcomings or oversights in the current policy.

\section{Dependent legal status and derived social and economic rights for Turkish women}

The German federal and Länder governments are coming under increasing pressure from women's rights organisations and legal rights organisations to find a solution to the growing problem of protecting especially young Turkish-Muslim women from abusive family situations where their rights are ignored and abused, and where there are abused too. The costs of continuing to ignore TurkishMuslim women's particular circumstances are rising. These costs are partly related to the funds that the German federal and Länder governments are investing in immigrant women's shelters and legal and other aid and counseling for immigrant women across Germany. There are a growing number of shelters around Germany that 'cater specifically to immigrant women... [and] [t]he majority of these organizations receive government support or funds in one form or another (Elbaum, 2006). Many of the women assisted are of Turkish-Muslim descent, escaping abusive home situations (Elbaum, 2006; Poggioli, 2008). Domestic violence against women in the Turkish-Muslim immigrant 
communities is rife - a German government report published in 2004 claimed that ' 49 percent of Turkish women had experienced physical or sexual violence in their marriage' (Poggioli, 2008). Further, in the last decade there have been 49 reported cases of honour killings ${ }^{12}$ (explain this in endnote first time you us this), 16 in Berlin alone (Poggioli, 2008). However, in spite of the widespread nature of this abuse, and the apparently lengthy periods of time over which the abuse is suffered by some women, this information is not widely known in Germany, and very little has been said about it in terms of federal or state policy. It is clear that there is a big problem here that the immigration policies, both those currently in place, and those that have been developed since 1998, are not able or willing to address.

Women's rights activists in Germany argue that German legal and political stances are condescending towards Islam, in that they try to account for Muslim religious and cultural beliefs and practices in an attempt to be inclusive, but what they end up doing in the process is denying women especially basic human rights, like the right to live free from sexual and physical abuse (Poggioli, 2008). Turkish-Muslim women find themselves in particularly difficult space. Many of them come to Germany as wives and young mothers, having been forced into arranged marriages with older cousins or other relatives at a very young age, and then moved to Germany. Many of these young women are unhappy and suffer abuse at the hands of their often much older husbands, many of whom believe that they need to keep their wives (and daughters) safe from the 'evils of Western secular societies' (Poggioli, 2008). Once in Germany, they try to find a space for themselves away from their unhappy and constrained home lives, and many end up dating German men, or working outside of the home or family business, and trying to lead more normal 'Western' lives. These women have to leave home to do this, as they are unable to stay for fear of retribution or further abuse and because many families would never allow or sanction such choices. Many women then, it is argued, live behind walls of silence; many are uneducated and illiterate in the social and cultural practices of their host country, and are unable to integrate because they are not fluent in German and are unable to leave their silent 'prisons'. Many also fear leaving their cultural and religious practices behind because within them is an element of safety - it is what they know and have known all their lives.

At the heart of the matter is a complicated dance between Germany's inability to fully embrace immigrants, many of whom were invited Turkey to fill labor shortages, and the immigrants' unwillingness to let go of behaviors and traditions that appear brutal to mainstream Western Europeans. Critics of Germany's record with guest workers say that the country has been standoffish with the new 
residents, leaving them clinging to their homeland's culture for a sense of familiarity and belonging, a phenomenon particularly true among Muslim immigrants (Elbaum, 2006).

The challenges facing immigrant women in Germany may seem new, but Turkish women have been migrating to Germany for as long as their male counterparts have, and they faced similar legal and social barriers to the ones facing current migrants. Feminist migration theorist Elenore Kofman argues that in Germany in particular during the period of guestworker recruitment, between 1960 and 1973 , there were many single and married working women, often without their children, present 'on the books' as it were (1999: 4). From 1964 onwards, one quarter of labour migrants from Turkey were women, and by the early 1970 s they formed the single largest group of female labour migrants (1999: 4). In spite of their considerable presence, as a result of women largely being regarded as incapable or unlikely to be independent labour migrants in their own right, and as a result of the fact that most women who have entered Europe since 1973 have done so as dependents through the process of family reunification, women confront greater difficulties than men do in obtaining independent work and residence permits. Kofman states that this 'dependency makes women particularly vulnerable to the regulations of nationality law and confirms the failure to treat women as members of society outside of their familial roles. Their rights are thus derived from their male sponsors' (1999: 7). Other feminist migration theorists pick up these issues. F. James Davis and Barbara Sherman Heyl argued, in 1986, that the subordinate status of women in Turkey migrates with guest workers into Germany, although there is greater space in the country of settlement for changes in the family structure to occur that may move women into a more egalitarian relationship with men (Davis and Heyl, 1986: 179). They argue that when Turkish women move into Germany they confront what they call 'threefold discrimination', which basically means that they are discriminated against because they are Turks, women, and migrant foreigners (1986: 179). Discrimination against migrant women in particular stems in part from the fact that, in spite of increasing numbers of migrants entering their borders, most EU member states still struggle to view themselves as active countries of immigration, welcoming migrants in both policy and practice.

Part of the problem in Germany, as at EU level, is that women are not necessarily awarded an independent right to work and residence if they arrive as dependants through family reunification. Before dependants are even given leave to travel to Germany for the purposes of reunification, certain conditions have to be met pertaining to housing size and stable employment and income. In many cases, spouses are only allowed to travel to Germany if the resident partner has a 
settlement permit, or has had a residence permit for at least five years, and only children up to the age of sixteen are allowed to join their parents in Germany. ${ }^{13}$ Further, after the spouses' reunion, the dependant has to wait in many cases from three to five years before an independent residence permit is awarded, and also for a work permit (EG-MG(1996)o2rev+11: Part II, V.a.ii).

In many cases, particularly for Turkish-Muslim immigrant women, this dependency makes them more vulnerable to abusive domestic situations from which many are unable to escape. Even though divorce or separation can be grounds for deportation before this period of time is up, residency rights can now be extended to women who leave their marriages, provided that the marriage was in place for two years after moving to Germany. In addition, authorities are given the discretion to extend residency rights to women who leave their husbands before the two-year period expires as a result of domestic violence and abuse (A Manual for Germany, Foreigners from Non-EU states: family reunion). Even though this is a valuable step towards empowering immigrant women legally, women who migrate as dependents do struggle to achieve independent rights and legal status, and many are unable to leave abusive situations because they are unable to find the help they need, legally, socially or otherwise. In addition to domestic abuse, a lack of independent rights to work forces many immigrant women into undocumented and unprotected labour, which may result in economic and physical abuse as well.

In the case of Turkish-Muslim women, religious as well as social considerations impact on their ability to leave abusive marriages. Some women, particularly young women, may be forced to enter into arranged religious marriages before they reach the age of majority, usually eighteen, and research seems to suggest that many young women who enter Germany as dependants are subjected to arranged marriages within their ethnic enclaves. It is difficult for the federal government to legislate in cases where religious and cultural customs prevail. In 2007, for example, a Frankfurt judge refused a request from Muslim woman for a fast-track divorce on the grounds that the Koran disallowed such violence. This may have seemed like a form of religious tolerance, but in fact it allowed the judge to effectively dismiss that woman's rights (Poggioli, 2008). In spite of clear difficulties in applying secular Western law to specific religious and cultural contexts, the German government's stand on secularity could be extended to a general stand that privileges basic human rights and freedoms over religious and cultural practices that may restrict said rights and freedoms. For example, it has been suggested by groups that advocate for Turkish-Muslim women's rights that the federal government strengthen the laws governing the admission into Germany of Turkish-Muslim women who enter as young brides. For instance, 
women should be at least 18 years of age, and must be required to take language classes upon arrival. In addition, arranged marriages should be forbidden and there need to be means with which to prosecute parents who force their children, particularly their daughters, to marry against their will (Spiegel Online, 2004). In addition to providing language training, it is vital to provide immigrant women with opportunities for education and skills training that may be denied them in their country of origin.

It is apparent from data collected in many EU member states that Muslim women entering the Union suffer from high illiteracy rates, and low levels of skills training. It has been suggested that, especially in rural and peri-urban areas where family-run businesses may require unpaid family labour in order to make a profit, there is non-enforcement of schooling for girls. Girls are also not encouraged, in general, to seek out tertiary education and advanced skills training, as they are required to remain within the home after marriage. This general lack of education follows these women to Germany, particularly first generation immigrant women who are often more isolated than their daughters and granddaughters, and less able to move outside of their enclave because of their inability to interact with others in German, among other reasons. Thus, an important part of an overall immigration and integration strategy for TurkishMuslim women is education and mandatory language training. All immigrant women must be encouraged to take language classes, and opportunities must be created to allow women to take advantage of these courses, such as assistance with childcare and with reluctant husbands and fathers who may not permit attendance. Experts argue that is it essential to introduce human and women's rights education in grade school, to teach immigrant children a more liberal, rights-based view of society and to enable them to understand as they grow older, how German social and legal standards are set and regulated (Spiegel Online, 2004; Elbaum, 2006). In addition to grade school cultural and civic education for immigrant children, I argue that ethnic German children should be educated regarding human and women's rights. They need a civic and cultural education that will give them greater knowledge and insight into immigrants' culture and customs, even if only in a general sense. The federal and Länder governments to need to promote the exchange of information and ideas between native German and immigrant groups, which would further encourage successful long-term integration.

While providing women with language training and various job training and education opportunities is important, it is not enough. Turkish-Muslim immigrant women and indeed many immigrant women in general find it difficult to enter the workplace. There are restrictions in place that make it difficult for 
many immigrants, both men and women to find work at their particular skills levels, and immigrant women suffer from high rates of unemployment. What is needed are mechanisms to encourage both job training and job placement at appropriate skills levels, and immigrant women need more active representation locally, provincially and nationally at federal level. If the government awards immigrant women independent work permits upon arrival, and facilitates their acceptance into training programmes, in addition to formally recognising any skills and qualifications they have brought with them, these women will be equipped with the tools to find and take on appropriate employment, both inside and outside of their 'ethnic enclave economies'. An ethnic enclave economy is described as a 'geographical cluster of ethnic firms with vertical integration of coethnic manufacturers, workers and consumers', also considered to be a substitute environment for the immigrants insofar as it had the capacity to provide them with a path for upward mobility (Portes and Bach, 1985 quoted in Hillmann, 1999: 268). 'Reciprocal obligations' and 'ethnic solidarity' are seen as key elements of this kind of economy, and Felicitas Hillmann argues that these economies are growing and becoming important to the overall European economy. She also states that there is a significant amount of hidden and unpaid labour done by women in family-owned businesses, and that even though the enclave can technically provide women with employment, it does not support professional advancement for women in the same way it does for men (Hillmann, 1999: 269). A further disadvantage of enclave employment for women is that the enclave 'provides women with very low wages, minimal benefits and few opportunities for advancement' (Gilbertson, 1995: 668, quoted in Hillmann, 1999: 269).

Hillmann's brief study of Turkish women entrepreneurs in Berlin suggests that entrepreneurship can give women unique opportunities to create a supportive and successful work environment for themselves in a labour market that is difficult to access. Greater support for women entrepreneurs would help many immigrant women to gain more financial and social independence and integration. By support what is meant is more banks willing to secure loans for women entrepreneurs, and more financial support for organisations set up to assist immigrant women with starting and running a business. While entrepreneurship does tend to push women out of their homes and into the workplace, both as employers and employees, there is little support or no support for these women at home. Many women carry a double burden because after their paid work is done their unpaid work at home with household and child-care responsibilities is still waiting (Hillmann, 1999: 269). Therefore I argue that an important part of any job creation and training initiative for immigrant women needs to include provision for affordable and reliable childcare to ease the double 
burden borne by so many women and to free them to really capitalise on any work opportunities they make have access to.

Linked to this discussion on ethnic enclave economies, and ethnic entrepreneurship within these economies, is the suggestion by Der Spiegel that part of the solution to the problem of integrating immigrants is to break up the Turkish-Muslim 'ghettos' (Spiegel Online, 2004). Ghettoisation allows the immigrant community to isolate itself as a whole, furthering ignorance of German social, cultural and political life and of the German language. It allows ethnic enclave economies to flourish, and while these are important to the EU economically, they enable the enforcement of unpaid work for women and may keep women away from job training and work opportunities that would allow them to experience life outside of the ghetto. The people who suffer most from ghettoisation are the youth, who need to integrate themselves into German society in order to feel that Germany is their home. The argument is that if they are able to integrate into a wider German community, over the long-term younger generations will feel less inclined towards an extremist affiliation to their ethnic group and will remain in Germany, working to contribute to the economy and raising families that will stave off serious demographic decline EGMG(1996)O2rev+11: para. 79). Perhaps one way to break up ethnic enclaves, forcing Turks to integrate further with the wider German community, would be to require entrepreneurs to serve a certain number of clients outside of their enclave. This requirement could be added in the Zuwanderungsgesetz in the section on entrepreneurs, who now have the opportunity to obtain work and residence permits provided they meet certain criteria (Munz, 2004). This may help Turks to create a wider social and economic network on which to build and could give women employed in ethnically isolated businesses exposure to the wider community and mitigate some of their cultural isolation and invisibility. Another way to assist women to both integrate successfully, and to find support and assistance with issues ranging from domestic abuse and childcare to business training and advice, is to create and fund women's organisations in areas with high concentrations of immigrants, like the big cities and towns.

Women's organisations require support from the federal government, which needs to take the human rights abuses suffered by immigrant women seriously. This would involve making funding available for further research into TurkishMuslim women's experiences of the process of immigration, and settled life in Germany, and funding for programmes like education and skills training that will enable these women to find paid work both inside and outside of their ethnic enclaves. It would also be beneficial to the cause of immigrant women's rights to find ways in which to allow immigrant women to participate in their own political 
representation at local, provincial and national level. Part of the social citizenship that legal immigrants are accorded is certain obligations to the German state, like paying taxes and contributing to pension schemes. But another part of social citizenship is obligations to immigrants by the German state, such as providing access to work, housing and social welfare, as well as ensuring that immigrants have a voice that is heard in appropriate forums. Perhaps a start could be to hold local conferences and workshops where women's NGOs and immigrant women could work together to present immigrant women's issues to a wider forum, and begin a campaign of awareness and information-sharing that would have longterm benefits for both immigrants and the host population. Non-immigrant citizens would learn more about immigrants, in particular Turkish-Muslim immigrants, and immigrant women would be able to meet people outside of their enclaves, learn more about the communities in which they live and empower themselves through active participation in political and social life.

According to Alice Schwarzer, a prominent German women's rights advocate, the subjugation of women, and especially immigrant women is a political, not a cultural issue. She argues that immigrant women deserve rights and Germans need to stand up and fight for them. In her words: "A society in which a male can put down another only because she is female - such a society is at its core an unfair society" (Spiegel Online, 2004). I would add that any society in which one person can put another down simply because that person is an immigrant is also at the core an unfair society, and Germans need to realise that ignoring immigrants' voices and denying them rights is not going to make immigration less of an economic and social reality. Valuable though the interventions and provisions made in the 2005 Act are, they can only help to a limited extent if the federal and Länder governments are not going to shift their position on immigrants to create a much deeper and more meaningful commitment to welcoming them into German political, social and cultural life. Integration has to go beyond prescribing and paying for language classes and civic education courses. It even has to go beyond awarding and extending residence permits and work permits. If Germany, like other EU member states, continues to regard itself, even privately, as a reluctant country of immigration, as I believe it still does, then no number of policy improvements and changes are going to really alter the reality of migrants, and migrant women's, lives. Xenophobic tendencies towards immigrants in Germany are strong, and widespread, and new right-wing, anti-immigrants groups are forming and gaining in strength. This is a serious problem that needs to be addressed. The disjuncture between what is written into law and how those laws are interpreted and lived is wide in parts of Germany, particularly where the conservatives hold sway. I do not believe that Germany can address the significant need to integrate and immerse immigrants in cultural, 
social and political life without seriously rethinking its deep-rooted and fundamental attitude towards 'others'.

\section{Xenophobia and the need to take account of immigrants' lived realities}

Xenophobia and right-wing extremism is Germany is on the rise, and people who hold right-wing views are drawn from all sectors of society - young and old, employed and unemployed, middle and working class. A survey conducted in Germany in May and June of 2006 showed that almost a quarter of the 5000 respondents agreed with xenophobic statements, and the number was higher in eastern Germany (Spiegel Online, 2006). The report on the survey concludes that these numbers are significant and xenophobia often leads to right-wing extremism and violence, and that is a 'scandal' that far-right views are so prevalent. 'Right-wing extremism is not an individual problem but one of society. ...The fact that it has come to this touches the foundations of democratic society' (Spiegel Online, 2006). A recent attack in 2007 on eight Indian men in Múgeln, in the former East Germany, has sparked a heated debate about the extent and depth of right-wing extremism and xenophobic sentiment in Germany, particularly in the former East Germany. This debate is instructive in regards to the kind of social and cultural environments immigrants are moving into and integrating with, and can go some way to explaining why, in spite of the more inclusive and open policies, Muslim immigrants in particular and very resistant to 'cultural integration' (Bisin et al., 2007).

The debate centres on whether or not the attack was racist, or motivated by rightwing extremism. An examination of comments made by newspapers and politicians on the left and right of the political spectrum provides a very clear indication of the dichotomy between the German federal government's zerotolerance policy on such behaviour, and what is actually happening and being tolerated in many parts of Germany. On the one hand, the centre-right Frankfurter Allgemeine Zeitung reports that:

It is almost symptomatic for failed integration in Germany that Turks and other immigrants are clearly under-represented at street and village celebrations, compared to their presence elsewhere. Just the fact that a group of Indians were partying and dancing with the locals in a beer tent after midnight is a point in Mügeln's favor. That would probably not have happened in other small towns with right-wing extremist problems. But now Mügeln is being depicted as just such a hotbed of racism in the media reports which have made the town infamous overnight. The talk is of a race-hate attack on Indians, of racist slogans and an 
applauding mob of onlookers. The police task force should clarify what really happened (Spiegel Online, 2007).

On the other hand, the center-left Berliner Zeitung writes:

The attack on eight Indians by approximately 50 Germans is a scandal, but the evil in Mügeln is not yet over. The mayor of the municipality played down his original statements one day after the incident: If the act was committed by rightwing extremists, then they came from somewhere else, and he did not hear the racist slogans which others reported. ... There have always been brawls at street parties -- fights have been part of the celebration for centuries. But in the case of Mügeln the violence was directed against foreigners, against an outwardly recognizable minority, and not against the usual drinking buddies. The epistemological hair-splitting of the German authorities therefore looks like an appeasement. The attack, the curious onlookers who did not intervene, the late arrival of the police and then the authorities' attempts to play down the incident - are they not all characteristics of one and the same culture? (Spiegel Online, 2007).

Looking at these two very different accounts of the same event, one can see that the tendency of the right is to downplay the fundamental understanding of the Indian immigrants as outsiders to that place and situation - as the 'Other' - and to highlight an arguably false sense of Múgeln as welcoming to immigrants. The comment seems to be blaming the media for over-emphasising the xenophobic motivation for the attack, to try and ignore that it exists. The tendency of the left, in comparison, is to acknowledge that there is indeed too much 'epistemological hair-splitting' and that what is needed is a shift in the culture - a fundamental shift in not only policy-making but also in attitude at all levels of society. This is indeed an overwhelming challenge for a country that has a deeply troubled past where immigrants and foreigners are concerned, and that perhaps finds itself stuck between the necessity of immigration and the unwillingness to confront the accompanying reality in full.

Dietrich Thränhardt and Robert Miles argue that immigration is indeed a 'structural necessity' (1995:1) for Europe at present, and will continue to be so in the future. There is no longer a need in Western Europe for mass unskilled labour migration, and thus immigrants are now more stringently screened and potentially excluded than they would have been during the 1960s and early 1970 s when such a need was present. Underlying immigration and integration policy at both national and supra-national level are utilitarian economic considerations and racist conceptions of 'otherness' (Thränhardt and Miles, 1995: 3). Unskilled 
and poorly educated migrants are a potential drain on already overtaxed pension and welfare systems within member states, and these migrants are perhaps more likely to be the target of racist attacks as they are particularly difficult to integrate through the usual routes of work and training programmes. This raises a key issue at the heart of particularly German debates about migrants and their inclusion into German society: citizenship rights.

Key to the logics of inclusion and exclusion is the issue of citizenship. Labour migrants immigrating to other EU member states from countries within the union, for example, Italians moving to Germany, are subject to the logic of inclusion through the acquisition of 'Euro-citizen status'.. Labour migrants who move into the EU from countries outside of the Union, even those that are connected to the EU through OECD and European Economic Community (EEC) membership, like Turkey, are not citizens and thus are subject to the logic of exclusion (Thränhardt and Miles, 1995: 8). Christian Joppke argues that citizenship is not only a set of rights, but also a 'mechanism of closure that sharply demarcates the boundaries of states' (1999: 629), and that in spite of this, citizenship is 'indispensable for integrating immigrants' and must thus be reframed (629). Germany has gone some way towards reframing citizenship rights, shifting the basis for awarding citizenship from ius sanguinis (blood ties to Germany) to ius soli (residence in Germany). The government, in 2000 passed laws that give all children born to foreigners resident in Germany citizenship status, provided one of their parents has been a permanent, legal resident for at least 8 years prior to the birth (Oezcan, 2004). Dual citizenship is held until the child is 23 , at which time they have to decide which citizenship they would prefer to hold, and give up the other. Long-term permanent residents are now also eligible for citizenship, although stringent conditions need to be met in order for this to be awarded, related to housing, employment and demonstrable civic knowledge and language ability. These revised and more open citizenship laws are an important step towards greater integration of migrants, and many feel a very necessary one.

There is, however, a growing debate around the issue of 'post-national membership' of EU member states, which, it is argued, has rendered full citizenship unnecessary for immigrants, who through the obtainment of a strong form of social citizenship now have sufficient rights and become successfully integrated into their 'host' communities (Joppke, 1999: 630). Thomas Faist defines social citizenship as the medium that allows immigrants to share in the economic and social benefits and responsibilities awarded to citizens of a state, like paying tax and drawing welfare payments, without any of the accompanying political rights and responsibilities, including the right to vote and run for 
political office. Faist argues that the 'main difference between citizens and noncitizen immigrants concerns the type of social benefits' they are awarded (Faist, 1995: 178-179). He states that Germany has been an example of an 'ethnocultural exclusionary model' of immigration and integration (Faist, 1995: 179), as such allowing settled immigrants to become full members of the economic community, but previously denying these immigrants the right to full citizenship because of its insistence on descent as the basis for citizenship over residence. Further he argues that Germany requires its immigrants to demonstrate a high degree of cultural assimilation in order to make an application for full citizenship but has only very recently made specific provisions for integrating and assimilating immigrants into German cultural life, as this paper has demonstrated. Faist argued for a policy of 'reciprocal immigration and integration' (1995: 190), where immigrants will learn the German language, immerse themselves to a significant extent in German cultural life and form a voluntary and lasting affiliation to Germany as state and nation, while the German state will make achieving citizenship through naturalisation a realistic goal for migrants through provision of language and culture courses, and opportunities for migrants to immerse themselves in their host communities. This goal is in sight, as these language and culture courses are in place, but as this paper has shown, there are significant challenges to creating these opportunities and achieving the required level of immersion of immigrants necessary for them to demonstrate the language and cultural knowledge needed to apply for and be granted citizenship.

Proponents of social citizenship argue that exclusionary citizenship no longer matters because former guest workers have achieved 'safe membership' of the nation in terms of permanent rights to work and residence. Joppke questions this argument, claiming that in spite of acquiring social citizenship rights and benefits, full political citizenship will remain an integral part of integrating immigrants, particularly from second and subsequent generations for whom xenophobic and racist violence is a very real threat, and that social citizenship will not be sufficient to protect immigrants from racist and xenophobic harassment (Joppke, 1999: 637). Current literature on the future of international relations in our increasingly globalised world suggests that this assessment is accurate.

International Relations theorists point to forces of integration and disintegration pulling against one another. As the world becomes increasingly globalised, particularly with regards to trade and economic cooperation, we see a growing global culture, where people in very different socioeconomic spaces can watch the same Hollywood movies, wear the same brand-name clothes, connect and share 
through websites like Facebook and MySpace, and listen to the same music. Linked to this, of course, is the fact that various forms of liberal, capitalist democracy are found in all states in the West, and are being introduced in developing parts of the world, and the former Eastern Bloc states, like new EU members states Lithuania, Belarus and Slovakia. Coupled with this is a growing argument for a form of global citizenship, which the EU to some extent embodies with its supranational character; one can be a German citizen but at the same time see oneself as European. These three elements, coupled with increased economic and military cooperation, create a more integrated and interdependent global space. But, at the same time, there is increasing evidence of disintegration - the fracturing of societies and polities along ethnic and cultural lines. The voice of the right-wing in Western Europe is becoming louder and more people are listening to what the right wing politicians have to say on immigration and integration polices and debates. There is a growing groundswell of support for these parties, like the Vlaams Belang (Flemish Interest) in Belgium, The National Front in France and the neo-Nazi National Democratic Party in Germany. In Cologne, Germany, a group of young people with their roots in the nationalist sentiments of the far right have launched an anti-Islamic party that is inspiring other similar movements across Germany. These young people protest against Muslim immigrants in their communities, evidenced for example the building of mosques, and play to citizens' fears of a 'Muslim invasion'. They have gained enough support to warrant their surveillance by the Office for the Protection of the Constitution, which fears they may gain sufficient support to claim parliamentary representation in 2009 (Brandt and Kleinhubbert, 2008).

It is not too extreme, I believe, to claim that xenophobia and right-wing extremism in Germany is a serious, and deeply-rooted problem. It is not, as I have argued in previous research, a significant threat to immigration, as the statistics will show. It has been acknowledged, though, that attacks like the one in Mügeln are damaging Germany's regional and national reputation, and could pose a threat to future investment, and could begun to persuade potential immigrants to move elsewhere. Germany is lagging worryingly behind the rest of the EU member states in implementing the EU's directives on investigation and prosecution of racist and hate-related crimes. This directive was issued in 2000 and Germany implemented it in 2006. This does not signify a government that is willing to make immigrants at home in Germany, and it does not inspire much confidence in Germany's ability to really close the gap between the rhetoric of immigration as a reality and the implementation of the policies that make it so. 


\section{Conclusion}

By the end of 2002, over 7.3 million non-nationals were resident in Germany, accounting for approximately $8.9 \%$ of the population including almost 2 million Turks, the largest immigrant group (Green, 2004: 5). Women account for almost half of the total immigrant population in Germany, as well as over 40 percent of the Turkish population (Hillmann, 1999: 270-271). Turkish women were recruited before the 1973 ban on Gastarbeider recruitment, and many married and single women responded, often moving alone to Germany to work in mass industry and in agriculture (Davis and Heyl, 1986: 183). Since 1973, women have been migrating to Germany, and the EU at large, through the mechanism of family reunification. This has resulted in a bias in much of the mainstream literature on migration in Europe, which tends to regard women as dependent migrants only, incapable of moving independently of men, and for the purposes of labour, skilled or unskilled. This paper focuses on immigrant women, and in particular Turkish-Muslim immigrant women who are dependent on their male sponsors, as this is an area where women's rights are tenuous, and largely unconsidered by German immigration policy.

Germany has a strong background of ethno-cultural solidarity and often-violent exclusion of those who do not belong in the dominant ethnic and cultural fold. The SPD/Green government planned for and negotiated the new Immigration Law since it gained power in 1998 as part of an attempt to write a new German history - one that is inclusive of and welcoming towards other ethnicities and cultural groups - and while it did not succeed in passing all the reforms it originally planned for, it succeeded in making some valuable changes to the status of immigrants in Germany. The most valuable reform is that regarding integration, specifically the provision of language and civic education classes for all incoming immigrants. Other reforms to allow entrepreneurs to gain work permits under certain conditions and to extend residence rights to women, even if they have separated from their husbands, before they have earned independent rights of residence and work permits, are also important steps towards recognising the contribution immigrants can make to German economic, social and cultural life, and awarding them comprehensive socio-economic right

There are, though, areas where Germany still fails to take seriously enough the issue of immigrants' rights, and the rights of immigrant women in particular. Germany in particular has a very large Turkish-Muslim population, and since 1996 has witnessed 49 documented honour killings perpetrated against young Turkish-Muslim women by male members of their own families (Poggioli, 2008). The German government has attempted to take a stand on secularism over religious fundamentalism, but the efforts made thus far have not been sufficient 
to truly provide for and protect the rights of these and other immigrant women. Turkish-Muslim women are often isolated from the wider German communities in which they live, and are by-and-large invisible victims of arranged marriages, unpaid family labour and in many cases domestic violence and abuse. An important part of the solution to these difficulties faced by immigrant women is to award those entering Germany as dependants independent work and residence permits, so that they do not have to stay in abusive relationships, or take unpaid or undocumented work which makes them vulnerable to further abuse and exploitation. Suggestions for other parts of an overall solution include strengthening laws that govern the admission of Turkish-Muslims to prevent underage and forced marriage; mandatory and supported language and civic education for incoming women immigrants; job training and job creation programmes for Turkish women, including support for entrepreneurial opportunities; and the de-ghettoisation of ethnic enclaves while creating wider support networks for women who need help moving outside of the enclaves to find work and residence. Working immigrant women also need assistance in finding affordable and reliable childcare to alleviate the 'double burden' of having two full-time jobs both outside and inside of the home, and to enable them to take advantage of any job training and creation programmes they may have access to.

The first, and most important issue that immigrant women confront is their dependent legal status. Women who enter the EU and Germany for the purposes of family reunification are allowed to do so because their husbands have residence or settlement permits and legal work that enables them to support their families. In Germany very strict conditions apply in terms of housing and financial support for dependents before applications for reunification are approved. On arrival, these women are awarded dependent residence status, and in most cases are only allowed to apply for their own independent permits after a period of between three and five years (EG-MG(1996)o2rev+ 1: part II; IV). They therefore have no independent legal standing, holding derived rights only. This lack of equal legal standing with immigrant men, and the citizens of the host country, creates a broad situation in which women are vulnerable to different kinds of physical, emotional and economic abuse in the workplace, in the home and within their host communities.

In addition to problems directly related to their dependent legal status, and in spite of policy provisions, immigrant women in the EU also struggle to obtain language training in German, and also have difficulty accessing job and skills training that would enable them to find paid work relevant to their skills levels. Immigrant women will continue to remain isolated and invisible within host 
communities unless they are able to meet people outside of their ethnic enclaves, and they need to speak German in order to do this successfully, for social and economic purposes. Immigrant women also have low participation levels in the workplace, possibly due to a combination of religious and cultural factors that may prevent women from finding paid labour outside of the home, and cultural and racist discrimination that may exclude them from certain sectors of the labour market where they could find such work. Immigrant women, most of whom do not hold political citizenship in their countries of residence, may struggle to find political and social representation, particularly in countries like Germany that have a long history of anti-immigrant sentiment. This lack of representation can lead to a lack of wider awareness of the difficulties facing immigrant women in Europe, and a lack of funding and support for initiatives to assist immigrant women with assuring their legal status and rights, education and training and access to the labour market.

An obvious first part of an overall solution is to award immigrant women entering member states independent rights of residence and work permits, either immediately upon arrival or after a much shorter period of time. Lack of independent legal and residence status often forces abused women to remain in their marriages to avoid being deported, at least until they are able to apply for their own permits. One way in which Germany has attempted to prevent longterm domestic abuse is to make provision for the awarding of independent rights of residence to women who leave abusive marriages before the specified time period is up. Another part of the solution for women, after awarding them independent rights to work and reside in Germany, is to educate them. Mandatory language education upon arrival in the host country is something Germany has incorporated into their legislation relating to integration. In addition to language education, it was suggested, specifically for Turkish women in Germany, but applicable to all immigrant women in the EU, that job training and job creation programmes need to be created for minority immigrant groups of women who suffer from comparatively high levels of unemployment, and who struggle to find work commensurate with their skills levels. I argue that in conjunction with this important initiative, immigrant women need assistance with finding affordable childcare, and in some cases housekeeping help, so that they can take advantage of training and job opportunities without being unduly constrained by their work and responsibilities at home. It is also essential that cultural and language education be emplaced in grade schools, for both immigrant and native European children, to teach the values of cultural diversity, and to ensure more successful integration of immigrant families as a whole. For many immigrant Muslim women, intervention is also needed with their husbands 
and fathers, many of whom are resistant to the immersion of women into German cultural and social life.

Therefore, immigrant women need access to better support networks in the form of legal aid and advice, women's shelters and call centres that can offer them assistance in cases of domestic abuse and violence, and labour support to prevent exploitation and discrimination in the workplace. Many of these organisations and institutions do exist, but their work needs to be better supported by both federal and Länder governments, and by German society as a whole. Another important part of immigrant women's integration and emancipation is more visible and audible representation of immigrant women's issues and interests at the level of the European Commission and the European Parliament, and at the level of national and provincial government in Germany. The Women's Committees of the European Parliament and the European Women's Lobby are achieving a level of exposure for immigrant women's issues at the supranational level, but there are few immigrant women on these committees, if any, and more of these women need to be encouraged to represent their own interests and form women's organisations that can be supported politically and financially. Immigrant women need to be encouraged at national level too, to be become more involved in representing their own interests socially and politically.

Germany has had difficulty drafting legislation that has a visible effect on the private sphere, where Muslim women especially are vulnerable to abuse, violence, isolation and exploitation. Germany has taken a stand on secularism, forbidding teachers and other public officials from wearing headscarves to work. The federal government has also signed and ratified CEDAW ${ }^{\mathrm{i} 6}$, which entails a commitment to preventing human rights abuses against all women. While there is no specific legislation in the Zuwanderungsgesetz to prevent private sphere abuses of women's human rights, a great deal of which is unseen by the majority of the host population, suggestions that the government begin to screen admissions of Turkish-Muslim immigrants to ensure that young women are not entering the country as underage brides in arranged marriages have been made. It has also been suggested that the government set the legal age for religious marriages at 18, and put in place legal mechanisms to prevent arranged marriages for young girls and women. These would be important steps towards ensuring that the rights of young Muslim women are protected and ensured.

Another area where Germany has struggled is in the prevention of uprisings of xenophobic and right-wing extremist sentiments. It is clear from numerous reports in German online newspapers, chief among them Spiegel Online, that right-wing sentiment, and outbursts of violence and active discrimination against 
immigrant minorities, are a significant obstacle to the successful and willing integration and immersion of immigrants into their host communities. If indeed right-wing political groupings are able to gain political representation, Germany could be facing a much more difficult fight against these divisive and damaging sentiments and the actions based upon them. It is very important for the German government to continue to examine and interrogate the processes through which permanent work and residence permits and citizenship are awarded, and must continue to make a firm commitment to valuing the human rights of immigrants by taking a visible stand against violence perpetrated against immigrant minorities, and against immigrant women. Violence against immigrants by German nationals, and violence against immigrants by their own kinsmen must be prosecuted to the fullest extent of the law, and these laws must have at their core a fundamental recognition of and respect for human rights over any religious or cultural concerns. Although it is undeniably important to respect the cultural and religious identities and customs of immigrant minorities, it is also important to create a clear set of laws and policies, and a firm set of implementation criteria that indicate that gross human rights violations, such as xenophobic and right-wing violence, domestic abuse and honour killings, will not be tolerated or excused. Immigrants do need to adapt to the dominant customs and political and social norms of Germany to successfully integrate themselves, and to contribute fully to German economic life - which is the reason for their recruitment in the first place.

However committed Germany may be to the primacy of human rights, it is clear from examining the legal documents outlining immigration policy that there is great deal more to be done to ensure the primacy of immigrants' rights, in particular those of immigrant women. If Germany could take a more progressive and open-minded stance on immigration, it could prompt other similarly exclusivist member states to follow suit, and this could filter up to a more open, rights-based immigration system at EU level as well. Immigration is part of Germany's economic and social reality, and will continue to be so for the foreseeable future. As long as immigrants continue to move into Germany their families will continue to move with them, bringing women and children into the country as well. These women deserve the same rights as the men whom they join have, and all immigrants deserve the same social and economic rights as the native citizens of their host countries. Women's rights are human rights, and human rights should no longer be a hollow term that politicians use to make their constituencies believe that people are being taken care of and respected. Human rights and women's rights must be firmly entrenched if Germany's rhetoric on the importance of integration and a less exclusive immigration regime is to mean anything at all. 


\section{References}

A Manual For Germany (Ein Handbuch fur Deutschland). Section: Foreigners from Non-EU States. Available online at:

http://www.handbuch-deutschland.de/book/en/003 002002 001.print.htm.

[Accessed July 2005.]

A Manual For Germany (Ein Handbuch fur Deutschland). Section: Discrimination and Equal Opportunities. Available online at:

http://www.handbuch-deutschland.de/book/en/003 004.print.htm. [Accessed July 2005.]

A Manual For Germany (Ein Handbuch fur Deutschland). Section: German Citizenship. Available online at:

http://www.handbuch-deutschland.de/book/en/003 003.print.htm. [Accessed July 2005.]

Biehl, Jody, K. 2005. ‘The Whore Lived Like a German'. 2 March 2005. Spiegel Online. Available from: http://service.spiegel.de/cache/international/o,1518,344374.00.html.

Bisin, A., Patacchini, E., Verdier, T. and Zenou, Y. 2007. 'Are Muslim Immigrants Different in Terms of Cultural Integration?' Institute for the Study of Labor, IZA DP No. 3006.

Ermine Bozkurt. Committee on Women's Rights and Gender Equality. European Parliament, 10 June 2005. 'Report on the role of women in Turkey in social, economic and political life (2004/2215(INI))'. Available online at: http://www.europarl.eu.int/committees/femm home.htm.

Brandt, Andrea and Guido Kleinhubbert. 'Anti-Islamic Party is playing with fear'. Spiegel Online. Available online at: http://www.spiegel.de/international/germany/0,1518,526225,00.html

Çağlar, Ayse, S. 2001. 'Constraining metaphors and the transnationalisation of spaces in Berlin'. Journal of Ethnic and Migration Studies, 27:4, October, 601 - 613.

Clarence, Sherran. 2001. "New nationalism" and xenophobia in the European Union: Is the future of immigration under threat? A German Case Study'. Major Research Project, B.A (Hons). University of Natal, Pietermaritzburg. Submitted November 2001.

Davis, F. James, and Barbara Sherman Heyl. 1986. 'Turkish Women and Guestworker Migration to West Germany'. In Simon, Rita James and Caroline B. Brettell (eds). International migration: the female experience. Totowa, NJ: Rowman and Allanheld, $178-196$.

Dettke, Dieter. 2001. 'Germany's New Immigration Policy'. Statement presented to Hearing on Germany of the Congressional Human Rights Caucus, October 11, 2001.

Available online at: http://www.fesdc.org/DD\%Speeches\%20+\%20Articles/Germany's\%20New\%20I mmigration\%20Policy.doc. 
Deutsche Welle (DW-World). 2008. 'OECD blasts German immigration policy'. $D W$ World [Online], 11 September. Available at: http://www.dwworld.de/dw/article/o,,3636129,00.html [Accessed 19 June 2009].

Exberliner. 2005. 'Press and Prejudice'. Exberliner - Berlin in English. Available from: http://cgi.exberliner.com/user-cgi-bin/feature.php?action=inthisissue.

[Accessed 17 May 2005.]

Elbaum, Rachel. 2006. 'Abuse and Germany's Muslim women'. ELBAUM.com. Available online at: http://www.Elbaum.msn.com/id/12812607/world newsislam in europe/print/1/dis... [Accessed 8 September 2009].

Faist, Thomas. 1995. 'Boundaries of welfare states: immigrants and social rights on the national and supranational level', in Thränhardt, Dietrich and Robert Miles (eds). Migration and European integration: the dynamics of inclusion and exclusion. Madison: Farleigh Dickinson University Press, 177 -195.

Green, Simon, Ph.D. 2004. The politics of exclusion: Institutions and immigration policy in contemporary Germany. Manchester; New York: Manchester University Press.

Heinrich, A. 2007. 'Integrating migrant women - active approach or mere rhetoric?' paper presented at an Intensive Program in Strasbourg, 2007. Available online at: http://www.euroculturemaster.org/pdf/groep7 2/Heinrich.pdf [Accessed 9 September 2009].

Hillmann, Felicitas. 1999. 'A Look at the "Hidden Side": Turkish Women in Berlin's Ethnic Labour Market'. International Journal of Urban and Regional Research, 23:2, $267-82$.

Hocking, B. and Smith, M. 1995. 'The Arena of World Politics'. In: World Politics: An Introduction to International Relations. Hemel Hampstead: Prentice Hall; Harvester Wheatsheaf, 29-49.

Inowlocki, Lena and Helma Lutz. 2000. "Hard Labour: The "Biographical Work" of a Turkish Migrant Woman in Germany'. The European Journal of Women's Studies, 7, 2000, 301 - 319.Joppke, Christian. 1999. 'How immigration is changing citizenship: a comparative view'. Ethnic and Racial Studies, 22:4, 629 652.

Martin, Phillip. 2001. 'Europe: A New Immigration Area?' Available online at: http://www.prb.org/template.cfm?Section=PRB\&template=/ContentManageme nt\%ContentDisplay.cfm\&ContentID $=5897$.

Münz, Rainer. 2004. 'New German Law Skirts Comprehensive Immigration Reform'. Migration Information Source. Fresh Thought, Authoritative Data, Global Reach. Available online at: http://www.migrationinformation.org/feature/print.cfm?ID=241.

Oezcan, V. 2004. 'Germany: Immigration in Transition'. Migration Information Source. FreshThought, Authoritative Data, Global Reach. Available online at: 
http://www.migrationinformation.org/Profiles/display.cfm?id=235 [Accessed 19 June 2009].

Poggioli, Sylvia. 2008. 'Muslim Women Behind Wall of Silence in Germany'. NPR. Available online

at: http://www.npr.org/templates/story/story.php?storyId=17819775. [Accessed 8 September 2009].

Schlagheck, Carola. 2003. 'Germany Topples EU Immigration Policy'. F.A.Z. Weekly, 11 July. Available from: http://yaleglobal.yale.edu/display.article?id=2094.

Spiegel Online. 2004. 'Germany's Lost Daughters'. 22 November 2004. Spiegel Online. Available from: http://service.spiegel.de/cache/international/o,1518,329060,00.html.

Spiegel Online. 2006. 'Far-Right Views Established Across German Society'. 11 August 2006. Spiegel Online. Available online at: http://www.spiegel.de/international/germany/0,1518,447255,00.html [Accessed 10 September 2009].

Spiegel Online. 2007. 'Zero Tolerance for "Everyday Racism”'. 21 August 2007. Spiegel Online. Available online at: http://www.spiegel.de/international/germany/0,1518,501049,00.html [Accessed 10 September 2009].

Thränhardt, Dietrich and Robert Miles. 1995. 'Introduction: European Integration, migration and processes of inclusion and exclusion', in Thränhardt, Dietrich and Robert Miles (eds). Migration and European integration: the dynamics of inclusion and exclusion. Madison: Farleigh Dickinson University Press, 1- 12. 


\section{Notes}

${ }^{1}$ This term literally means 'guest workers'.

2 This event was caused, essentially, by an embargo by the Organisation of Petroleum Exporting Countries (OPEC) sanctioned by Saudi Arabia in response to the West's support of the Arab-Israeli War.

3Also known as the former West Germany. The former East Germany was known as the German Democratic Republic, or GDR.

4 Translated literally this means 'policy towards foreigners' and encompasses immigration, residence, integration and citizenship policy.

5 Turkish guest workers began entering Germany after an agreement between the Turkish and German governments was signed in 1961, and Turkish workers formed the single biggest group of guest workers from late 1960 s onwards.

6 lit. 'Foreigner's Law', passed in 1965 and revised in 1990.

7 For a full discussion of the reform process and the issues it addressed see Green, Simon. 2004. The politics of exclusion: Institutions and immigration policy in contemporary Germany. (Manchester; New York: Manchester University Press), 5078.

${ }^{8}$ See Hillmann, Felicitas. 1999. 'A Look at the 'Hidden Side': Turkish Women in Berlin's Ethnic Labour Market'. International Journal of Urban and Regional Research, 23:2, 267-82.

9 This is especially the case for non-nationals whose labour had been recruited during the pre-oil shock years, for example, Turks.

${ }^{10}$ Literally translated it means 'Immigration Law'.

${ }^{11}$ Honour killings can be defined, broadly, as the murder by a male family member of a woman for reasons related to the perception or belief of her actions having brought shame on the whole family, for which the only remedy is her death. Recent honour killings in Germany have seen young women and mothers shot, drowned, stabbed and burned with acid.

${ }^{12}$ Upper house of the German parliament.

${ }^{13}$ For a full discussion of these restrictions see A Manual for Germany - Foreigners from Non-EU States: Family reunion. Available online at: http://www.handbuchdeutschland.de/book/en/003 002002 001.print.html. 14 Ethnic Germans from Eastern Europe who migrate to Germany.

${ }^{15}$ See Inowlocki, Lena and Helma Lutz. 2000. 'Hard Labour: The "Biographical Work" of a Turkish Migrant Woman in Germany' in The European Journal of Women's Studies, 7,30 -319; and Hillmann, 1999.

${ }^{16}$ Convention on the Elimination of All Forms of Discrimination Against Women, which all EU member states have ratified. 